\title{
Prevalence and correlates of vitamin D status in African American
}

\section{men}

\author{
Marilyn Tseng*1,2, Veda Giri ${ }^{1}$, Deborah W Bruner ${ }^{3}$ and \\ Edward Giovannucci ${ }^{4,5}$
}

Address: ${ }^{1}$ Cancer Prevention and Control Program, Fox Chase Cancer Center, Philadelphia, PA 19111, USA, ${ }^{2}$ Department of Kinesiology, California Polytechnic State University, San Luis Obispo, CA 93407, USA, 35chool of Nursing, University of Pennsylvania, Philadelphia, PA 19104, USA, ${ }^{4}$ Department of Nutrition, Harvard School of Public Health, Boston, MA 02115, USA and ${ }^{5}$ Department of Epidemiology, Harvard School of Public Health, Boston, MA 02115, USA

Email: Marilyn Tseng* - mtseng@calpoly.edu; Veda Giri - Veda.Giri@fccc.edu; Deborah W Bruner - wbruner@nursing.upenn.edu; Edward Giovannucci - egiovann@hsph.harvard.edu

* Corresponding author

Published: 18 June 2009

BMC Public Health 2009, 9:191 doi:10.1 |86//47|-2458-9-191
Received: 23 January 2009

Accepted: 18 June 2009

This article is available from: http://www.biomedcentral.com/I47I-2458/9//9I

(C) 2009 Tseng et al; licensee BioMed Central Ltd.

This is an Open Access article distributed under the terms of the Creative Commons Attribution License (http://creativecommons.org/licenses/by/2.0), which permits unrestricted use, distribution, and reproduction in any medium, provided the original work is properly cited.

\begin{abstract}
Background: Few studies have examined vitamin D insufficiency in African American men although they are at very high risk. We examined the prevalence and correlates of vitamin $D$ insufficiency among African American men in Philadelphia.

Methods: Participants in this cross-sectional analysis were 194 African American men in the Philadelphia region who were enrolled in a risk assessment program for prostate cancer from 10/ 96-10/07. All participants completed diet and health history questionnaires and provided plasma samples, which were assessed for 25 -hydroxyvitamin $\mathrm{D}(25(\mathrm{OH}) \mathrm{D})$ concentrations. We used linear regression models to examine associations with $25(\mathrm{OH}) \mathrm{D}$ concentrations and logistic regression to estimate odds ratios (OR) for having $25(\mathrm{OH}) \mathrm{D} \geq 15 \mathrm{ng} / \mathrm{mL}$.
\end{abstract}

Results: Mean $25(\mathrm{OH}) \mathrm{D}$ was $13.7 \mathrm{ng} / \mathrm{mL}$, and $61 \%$ of men were classified as having vitamin $\mathrm{D}$ insufficiency $(25(\mathrm{OH}) \mathrm{D}<15 \mathrm{ng} / \mathrm{mL})$. Even among men with vitamin $\mathrm{D}$ intake $\geq 400 \mathrm{IU} /$ day, $55 \%$ had $25(\mathrm{OH}) \mathrm{D}$ concentrations $<15 \mathrm{ng} / \mathrm{mL}$. In multivariate models, $25(\mathrm{OH}) \mathrm{D}$ concentrations were significantly associated with supplemental vitamin $D$ intake (OR $4.3,95 \%$ confidence interval $(\mathrm{Cl})$ I.5, I2.4) for $>400$ vs. 0 IU/day), milk consumption (OR 5.9, $95 \% \mathrm{Cl} 2.2,16.0$ for $\geq 3.5 \mathrm{vs.}<\mathrm{I}$ time per week), and blood collection in the summer. Additionally, 25(OH)D concentrations increased with more recreational physical activity (OR I.3, 95\% Cl I.I, I.6 per hour). A significant inverse association of body mass index with $25(\mathrm{OH}) \mathrm{D}$ concentrations in bivariate analyses was attenuated with adjustment for season of blood collection.

Conclusion: The problem of low vitamin D status in African American men may be more severe than previously reported. Future efforts to increase vitamin $D$ recommendations and intake, such as through supplementation, are warranted to improve vitamin $D$ status in this particularly vulnerable population. 


\section{Background}

In addition to its association with bone loss, fracture, osteomalacia, and other skeletal conditions, suboptimal concentrations of circulating $25(\mathrm{OH}) \mathrm{D}$ have been linked to non-skeletal chronic diseases, including cancer, diabetes, heart disease, autoimmune conditions, hypertension, andinfection [1-3]. Because the skin pigment melanin absorbs sunlight [4], the most important source of vitamin D [5], black adults are at particularly high risk for vitamin D insufficiency. Few studies, however, have examined vitamin D insufficiency in African American men, particularly in a northern climate that may place them at even higher risk [6,7]. We examined the prevalence and correlates of vitamin D insufficiency in a sample of community-dwelling African American men in the Philadelphia region $\left(40^{\circ} 00^{\prime}\right.$ latitude).

\section{Methods \\ Study sample}

Participants in the study were African American men enrolled in the Fox Chase Cancer Center (FCCC) Prostate Cancer Risk Assessment Program (PRAP). PRAP was established by FCCC investigators in 1996 to offer education and preventive interventions to men at potentially high risk for prostate cancer, and to serve as a research base for studying gene-environment interactions in prostate cancer [8]. African American men were eligible for the program if they were between 35 and 69 years of age and had no history of prostate cancer. Recruitment strategies included referrals from prostate cancer patients at FCCC, radio and newspaper advertisements, and physician and self-referrals.

Of 440 African American men enrolled in PRAP between October, 1996, and October, 2007, we excluded those who were recruited through satellite locations and whose plasma samples thus could not be processed immediately after collection $(\mathrm{N}=79)$; who did not provide a blood sample after July, 2000, when standard procedures were established for processing and storing plasma samples in the FCCC Biosample Repository $(\mathrm{N}=72)$; or who had a previous diagnosis of cancer $(\mathrm{N}=5)$. In addition, because the analysis was nested within a study of dietary intake and vitamin D status, men who did not return a food frequency questionnaire $(\mathrm{N}=73)$ or who reported an infeasible energy intake ( $<500 \mathrm{kcal} /$ day or $>4400 \mathrm{kcal} /$ day $)(\mathrm{N}=17)$ were excluded, leaving $194 \mathrm{men}$ available for these analyses.

Participants provided their written, informed consent to participate in study procedures. All procedures were in accordance with institutional ethical standards, and the project was approved by the Institutional Review Board at the Fox Chase Cancer Center.

\section{Data collection}

Upon enrollment into PRAP, men completed a health history questionnaire and the Harvard Diet Assessment Form
[9]. At initial and follow-up appointments, participants also contributed $51 \mathrm{~mL}$ of blood for storage in the FCCC Biosample Repository. The health history questionnaire elicited information on sociodemographic characteristics, occupation, family history of prostate cancer, smoking status, physical activity, and self-reported height and weight. Occupational sun exposure was assessed based on each participant's reported occupation, which was classified into one of three categories according to presumed sunlight exposure (indoor work, combined indoor and outdoor work, outdoor work), using an index that was related to mortality from non-melanoma skin cancer in previous studies [10-12]. The Diet Assessment Form elicited information on frequency of intake of 126 food items, and on length of use and dosage of dietary supplements.

\section{Assessment of plasma 25(OH)D concentration}

Concentrations of plasma 25(OH)D were determined by Heartland Assays, Inc. (Ames, IA) with a direct, competitive chemiluminescence immunoassay (CLIA) using the DiaSorin LIAISON platform [13]. The assay is co-specific for 25-hydroxyvitamin $\mathrm{D}_{3}$ and 25-hydroxyvitamin $\mathrm{D}_{2}$, so that total $25(\mathrm{OH}) \mathrm{D}$ is reported. Inter-assay variability estimated from other samples in the same laboratory ranged from $12.7-13.6 \%$, and intra-assay variability ranged from 9.3-11.0\% (personal communication).

\section{Statistical analyses}

We used linear regression models to examine associations of sociodemographic, lifestyle, and dietary factors with $25(\mathrm{OH}) \mathrm{D}$ concentration, and logistic regression models to estimate odds ratios for having $25(\mathrm{OH}) \mathrm{D}$ concentrations $\geq$ $15 \mathrm{ng} / \mathrm{mL}$ ). Cutpoints to define vitamin D insufficiency vary. We chose a cutpoint of $15 \mathrm{ng} / \mathrm{mL}$ to define the lower limit of the normal range of $25(\mathrm{OH}) \mathrm{D}$ concentration [5]. The same cutpoint has been used as a criterion to define low vitamin D status in other studies [14-16], including recent studies conducted among African American men $[17,18]$. While $30-32 \mathrm{ng} / \mathrm{mL}(75-80 \mathrm{nmol} / \mathrm{L})$ are other common cutpoints for optimal vitamin D concentrations with respect to a variety of health outcomes [16,19], too few men in our sample $(\mathrm{N}=2)$ had concentrations above $30 \mathrm{ng} / \mathrm{mL}$ to permit a sufficiently powered analysis.

Fortified foods such as milk ( 100 IU/cup) and cereal (often $\sim 40 \mathrm{IU} /$ cup) are the primary sources of vitamin D in the United States [5] and were therefore considered as predictors of vitamin D status. Milk intake was calculated as the sum of frequencies of intake of skim or low fat milk and whole milk. Intakes of alcohol, fish, and eggs were not associated with 25(OH)D levels in bivariate analyses and were not considered further.

Categorical covariates were coded using dummy variables to allow for non-linear associations across categories. Var- 
iables were included as potential confounders in multivariate models if they were significantly associated with 25(OH)D concentrations in unadjusted linear or logistic regression models. Variables that were not significant predictors in linear or logistic regression models were subsequently dropped. All statistical analyses were conducted using SAS for Windows version 9.1.2 (Cary, NC).

\section{Results}

Among the 194 African American men in our sample, mean (SD) age was 49.6 (8.4) years, and most men were either overweight ( $46 \%$ with body mass index (BMI) 25$<30 \mathrm{~kg} / \mathrm{m}^{2}$ ) or obese $\left(39 \%\right.$ with $\mathrm{BMI} \geq 30 \mathrm{~kg} / \mathrm{m}^{2}$ ) (Table 1 ). With respect to vitamin D status, only $39 \%$ had $25(\mathrm{OH}) \mathrm{D}$ concentrations $\geq 15 \mathrm{ng} / \mathrm{mL}$, while $27 \%$ had concentrations of $10-<15 \mathrm{ng} / \mathrm{mL}$, and $34 \%$ had concentrations $<10 \mathrm{ng} / \mathrm{mL}$ (Table 1 ). Only two men had concentrations $>30 \mathrm{ng} / \mathrm{mL}$.

In unadjusted, bivariate analyses, 25(OH)D concentrations were higher with lower BMI and with more recreational physical activity. Mean 25(OH)D was $15.0 \mathrm{ng} / \mathrm{mL}$ among non-overweight men vs. $11.5 \mathrm{ng} / \mathrm{mL}$ among men with $\mathrm{BMI} \geq 35 \mathrm{~kg} / \mathrm{m}^{2}$. It was $12.7 \mathrm{ng} / \mathrm{mL}$ among men who exercised $\leq 1$ hour/week vs. $15.4 \mathrm{ng} / \mathrm{mL}$ among men who exercised $>3$ hours/week. Concentrations were also higher with greater milk and cereal intake and with supplemental vitamin D intake, although concentrations and level of insufficiency were similar regardless of level of supplementation. Notably, even among men consuming at least $400 \mathrm{IU}$ of vitamin D per day, the recommended intake for men 51-70 years of age [5], mean 25(OH)D was only $15.0 \mathrm{ng} / \mathrm{mL}$, and $55 \%$ had concentrations $<15 \mathrm{ng} / \mathrm{mL}$.

Vitamin D concentrations varied with season as well, with the highest mean concentration $(18.0 \mathrm{ng} / \mathrm{mL})$ and lowest prevalence of insufficiency (31\%) occurring during the summer, and the lowest mean concentration $(10.3 \mathrm{ng} /$ $\mathrm{mL}$ ) and highest prevalence of insufficiency ( $80 \%$ ) occurring during the winter. Additionally, vitamin D concentrations were lowest in men with occupations categorized as being outdoor or mixed indoor/outdoor, and highest in men not currently working. We observed non-significant trends of increasing 25(OH)D with age, and lower 25(OH)D among current smokers.

In multivariate models, $25(\mathrm{OH}) \mathrm{D}$ concentrations were significantly associated with supplemental vitamin D intake and milk consumption, and significantly inversely associated with blood collection in fall, winter, or spring vs. summer (Table 2). In additional multivariate analyses limited to 136 men not missing data on recreational physical activity, 25(OH)D levels increased by $0.38 \mathrm{ng} / \mathrm{mL}$ with every additional hour per week of physical activity (Table 2). Notably, unadjusted, bivariate associations of
25(OH)D concentrations with BMI and occupational sun exposure were attenuated with adjustment for season; mean BMI was significantly $(\mathrm{p}=0.006)$ higher during winter $\left(31.2 \mathrm{~kg} / \mathrm{m}^{2}\right)$ than during summer $\left(28.2 \mathrm{~kg} / \mathrm{m}^{2}\right)$ months, and men with occupational sun exposure categorized as being mixed or outdoor were more likely to have contributed their samples during winter (32\%) than during summer (12\%) months.

\section{Discussion}

We noted very low concentrations of $25(\mathrm{OH}) \mathrm{D}$ and a very high prevalence of insufficiency (61\%) in a sample of adult African American men in the Philadelphia region, indicating a more severe problem of hypovitaminosis $\mathrm{D}$ than has been reported previously among African American men $[6,7,17,18,20,21]$. Comparison with previous studies is difficult because different cutpoints have been used to define insufficiency, and also because we did not use an external control to permit comparison with results from other laboratories. The lower mean $25(\mathrm{OH}) \mathrm{D}$ concentration in our sample than in African American men in Massachusetts (17$25 \mathrm{ng} / \mathrm{mL})$ [6,7] and Washington, DC (18 ng/mL) [18] may be due to variability in methods $[22,23]$. However, mean $25(\mathrm{OH}) \mathrm{D}$ concentration during summer months in our sample is only slightly lower than the mean of $\sim 20 \mathrm{ng} / \mathrm{mL}$ estimated for black participants in the Third National Health and Nutrition Examination Survey, which was conducted during the summer in northern states and during the winter in southern states $[21,24]$. It is comparable to mean concentrations estimated for black adults in regions with greater sun exposure - in particular, Arizona (18.2 ng/mL) [20], California $(18.1 \mathrm{ng} / \mathrm{mL})$ [25], and the South $(19.0 \mathrm{ng} / \mathrm{mL})$ [17]. This context supports the plausibility of the low vitamin D status observed in our sample.

We found large differences in vitamin D status by season, confirming the substantial contribution of season, particularly winter, to severe vitamin D insufficiency. We also found an association of physical activity with vitamin D status but could not assess whether the association could be attributed to sun exposure with outdoor activity [2628]. The significant associations for intakes of supplemental vitamin $\mathrm{D}$ and milk indicate the importance of measures to increase vitamin $\mathrm{D}$ intake to improve vitamin $\mathrm{D}$ status. In multivariate analyses, vitamin D supplement use increased mean 25(OH)D concentrations by $4.5 \mathrm{ng} /$ $\mathrm{mL}$, and milk consumption of at least 3.5 times per week increased concentrations by $3.3 \mathrm{ng} / \mathrm{mL}$ relative to consumption of less than once per week. However, even among men with total (dietary and supplemental) vitamin $\mathrm{D}$ intake of $>400 \mathrm{IU} /$ day, the recommended intake for men over 50 years of age [5], 55\% had 25(OH)D concentrations $<15 \mathrm{ng} / \mathrm{mL}$, suggesting that current dietary recommendations are not adequate to achieve optimal vitamin $\mathrm{D}$ concentrations in this population. 
Table I: Distribution of descriptive characteristics in 194 African American men', and associations with 25(OH)D concentrations.

\begin{tabular}{|c|c|c|c|}
\hline & Distribution (\%) & Mean 25(OH)D $(\mathrm{ng} / \mathrm{mL})^{2}$ & $25(\mathrm{OH}) \mathrm{D}<15 \mathrm{ng} / \mathrm{mL}(\%)$ \\
\hline Plasma 25(OH)D (ng/mL) & & -- & -- \\
\hline Mean (SD) & $13.7(6.1)$ & & \\
\hline$<10$ & 34 & & \\
\hline $10-<15$ & 27 & & \\
\hline$\geq 15$ & 39 & & \\
\hline \multicolumn{4}{|l|}{ Age (years) } \\
\hline Mean (SD) & $49.6(8.4)$ & & \\
\hline $35-44$ & 29 & 13.1 & 65 \\
\hline $45-54$ & 45 & 13.4 & 61 \\
\hline $55-74$ & 26 & 14.7 & 58 \\
\hline \multicolumn{4}{|l|}{ Level of education } \\
\hline high school graduate & 21 & 13.8 & 56 \\
\hline some college & 42 & 13.5 & 63 \\
\hline college graduate & 22 & 14.3 & 57 \\
\hline graduate degree & 15 & 13.1 & 69 \\
\hline \multicolumn{4}{|l|}{ Body mass index $\left(\mathrm{kg} / \mathrm{m}^{2}\right)$} \\
\hline Mean (SD) & $29.6(5.4)$ & & \\
\hline$<25$ & 15 & $15.0^{\mathrm{a}}$ & 50 \\
\hline $25-<30$ & 46 & $14.0^{\mathrm{ab}}$ & 57 \\
\hline $30-<35$ & 26 & $13.2^{\mathrm{ab}}$ & 67 \\
\hline$\geq 35$ & 13 & $11.5^{\mathrm{b}}$ & 76 \\
\hline \multicolumn{4}{|c|}{ Recreational physical activity (hours/week) } \\
\hline Mean or median & $2.3(2.1)$ & & \\
\hline$\leq \mathrm{I}$ & 42 & $12.7^{\mathrm{a}}$ & $74^{a}$ \\
\hline$>1-3$ & 34 & $14.6^{\mathrm{b}}$ & $48^{\mathrm{b}}$ \\
\hline$>3$ & 24 & $15.4^{b}$ & $45^{b}$ \\
\hline \multicolumn{4}{|l|}{ Occupational sun exposure } \\
\hline Indoor & 35 & $13.9 \mathrm{ab}$ & 58 \\
\hline Mixed/Outdoor & 18 & $12.0^{\mathrm{a}}$ & 68 \\
\hline Unknown occupation & 28 & $13.2^{\mathrm{ab}}$ & 67 \\
\hline Not currently working & 20 & $15.5^{\mathrm{b}}$ & 53 \\
\hline \multicolumn{4}{|l|}{ Smoking status } \\
\hline Never & 62 & 14.2 & 57 \\
\hline Former & 23 & 13.5 & 69 \\
\hline Current & 15 & 12.0 & 67 \\
\hline \multicolumn{4}{|l|}{ Total vitamin D (IU/day) } \\
\hline Mean (SD) & $371(331)$ & & \\
\hline$<200$ & 45 & $12.2^{\mathrm{a}}$ & 68 \\
\hline $200-<400$ & 21 & $14.4^{\mathrm{ab}}$ & 58 \\
\hline$\geq 400$ & 35 & $15.0^{\mathrm{b}}$ & 55 \\
\hline \multicolumn{4}{|l|}{ Dietary vitamin D (IU/day) } \\
\hline Mean (SD) & $181(114)$ & & \\
\hline$<200$ & 70 & 13.4 & 64 \\
\hline $200-<400$ & 24 & 14.2 & 59 \\
\hline$\geq 400$ & 7 & 14.3 & 46 \\
\hline \multicolumn{4}{|c|}{ Milk intake (8 oz glasses/week) } \\
\hline Median (| $\left.\right|^{\text {st }}, 3^{\text {rd }}$ quartile) & I $(0.5-3)$ & & \\
\hline$<1$ & 44 & 13.0 & $69 a$ \\
\hline $1-<3.5$ & 38 & 13.7 & $60^{\mathrm{ab}}$ \\
\hline$\geq 3.5$ & 18 & 15.2 & $46^{b}$ \\
\hline
\end{tabular}


Table I: Distribution of descriptive characteristics in 194 African American men', and associations with 25(OH)D concentrations.

\begin{tabular}{|c|c|c|c|}
\hline \multicolumn{4}{|c|}{ Cereal intake (cups/week) } \\
\hline 0 & 22 & $12.6^{\mathrm{a}}$ & 62 \\
\hline$\leq 1$ & 41 & $13.1^{\mathrm{ab}}$ & 67 \\
\hline$>1$ & 37 & $14.9 \mathrm{~b}$ & 54 \\
\hline \multicolumn{4}{|c|}{ Supplemental vitamin D (IU/day) } \\
\hline 0 & 55 & $11.9 \mathrm{a}$ & 73 \\
\hline$\leq 400$ & 32 & $15.8^{\mathrm{b}}$ & 46 \\
\hline$>400$ & 13 & $15.8^{\mathrm{b}}$ & 52 \\
\hline \multicolumn{4}{|c|}{ Season of blood collection } \\
\hline Summer & 26 & $18.0^{\mathrm{a}}$ & $31^{a}$ \\
\hline Fall & 24 & $13.8^{\mathrm{b}}$ & $61^{t}$ \\
\hline Winter & 29 & $10.3^{c}$ & 80 \\
\hline Spring & 21 & $12.7^{b}$ & 73 \\
\hline
\end{tabular}

The significant association between BMI and 25(OH)D concentrations in bivariate analyses was attenuated after adjustment for season of blood draw. In our sample, BMI was significantly higher in the winter $\left(31.2 \mathrm{~kg} / \mathrm{m}^{2}\right)$ than in the summer $\left(28.2 \mathrm{~kg} / \mathrm{m}^{2}\right)$, a phenomenon that has been noted in other studies [29,30]. The lack of association between BMI and 25(OH)D concentrations in our sample differs from previous studies, conducted primarily in white populations, that have noted an inverse association between the two [31]. Other evidence exists to suggest that adiposity may not be as strong a predictor of low vitamin D status among African Americans as it is in whites $[14,32,33]$.

A limitation of our study is that detailed information on sun exposure, such as time spent outdoors, sunscreen use, and other sun protection behaviors, was not available. Additionally, 21\% ( $\mathrm{N}=40)$ of our sample completed their questionnaires over a year before collection of their blood sample used in these analyses; however, analyses exclud-

Table 2: Multivariate adjusted betas and odds ratios (OR) with $95 \%$ confidence intervals (Cl) for $25(\mathrm{OH}) \mathrm{D} \geq \mathrm{I5} \mathrm{ng} / \mathrm{mL}$.

\begin{tabular}{|c|c|c|c|c|}
\hline & \multicolumn{2}{|c|}{ Multivariate' model $(\mathrm{N}=194)$} & \multicolumn{2}{|c|}{ Multivariate model + physical activity ${ }^{2}(\mathrm{~N}=136)$} \\
\hline & Beta $^{3}$ ( $p$-value $)$ & OR $(95 \% \mathrm{Cl})$ & Beta $^{3}$ ( $p$-value) & OR $(95 \% \mathrm{Cl})$ \\
\hline \multicolumn{5}{|l|}{ Supplemental vitamin D (IU/day) } \\
\hline 0 & ref & 1.0 & ref & 1.0 \\
\hline$\leq 400$ & $4.5(<0.0001)$ & $5.9(2.6,13.5)$ & $4.3(<0.0001)$ & $8.1(2.9,22.6)$ \\
\hline$>400$ & $4.5(<0.000 \mathrm{I})$ & $4.3(1.5,12.4)$ & $4.5(0.001)$ & $4.8(1.3,18.6)$ \\
\hline \multicolumn{5}{|l|}{ Milk intake (times/week) } \\
\hline$<$ | time/week & ref & 1.0 & ref & 1.0 \\
\hline $\mathrm{I}-<3.5$ times/week & $1.4(0.07)$ & $2.3(1.0,5.2)$ & I.7 (0.08) & $2.8(1.0,7.5)$ \\
\hline$\geq 3.5$ times/week & $3.3(0.001)$ & $5.9(2.2,16.0)$ & $3.1(0.01)$ & $6.6(1.9,23.6)$ \\
\hline \multicolumn{5}{|l|}{ Season of blood collection (\%) } \\
\hline Summer & ref & 1.0 & ref & 1.0 \\
\hline Fall & $-4.70(<0.0001)$ & $0.2(0.1,0.5)$ & $-4.34(0.0004)$ & $0.2(0.1,0.7)$ \\
\hline Winter & $-8.59(<0.0001)$ & $0.05(0.02,0.1)$ & $-8.56(<0.0001)$ & $0.04(0.01,0.2)$ \\
\hline Spring & $-6.22(<0.0001)$ & $0.1(0.03,0.2)$ & $-5.69(<0.0001)$ & $0.1(0.03,0.4)$ \\
\hline Recreational physical activity (hours/week) & -- & -- & $0.38(0.07)$ & $1.3(1.1,1.6)$ \\
\hline $\mathrm{R}^{2}$ & 0.40 & & 0.39 & \\
\hline
\end{tabular}

I Model including supplemental vitamin D, milk intake, and season of blood collection.

2 Model including supplemental vitamin D, milk intake, season of blood collection, and recreational physical activity.

${ }^{3}$ Betas represent absolute mean change in $25(\mathrm{OH}) \mathrm{D}$ concentration relative to referent category. For physical activity, beta represents absolute mean change in $25(\mathrm{OH}) \mathrm{D}$ concentration for each one-hour increase in recreational physical activity per week. 
ing these men produced no meaningful differences from results based on the full sample. Self-selection into the high risk program may have biased our estimates or may limit generalizability of our results, but African American men were required to meet no eligibility criteria to enroll in the program other than having no personal history of prostate cancer. Further, we saw no association of family history of prostate cancer with 25(OH)D levels (data not shown), nor is there reason to expect that self-selection into the program would be related to major determinants of vitamin D status. Our analysis included only 194 of the 440 African American men enrolled in PRAP. Men in our sample were more likely to be never smokers than were men not included in the analysis (62\% vs. $48 \%$ ), but the two groups were otherwise similar with respect to age, education level, BMI, and participation in recreational physical activity (data not shown).

\section{Conclusion}

In our sample of African American men, we found extremely low vitamin D concentrations and high prevalence of vitamin D insufficiency, suggesting a more severe problem of poor vitamin D status in this population than has been reported previously. Other notable findings were significant associations of vitamin $\mathrm{D}$ concentrations with supplemental vitamin D, milk intake, and physical activity, and the lack of an association with obesity. Although African Americans are at lower risk for osteoporosis and bone fractures, emerging evidence suggests that vitamin D protects against various inflammatory and autoimmune conditions, cardiovascular disease, cancer, and infection $[2,3]$. Thus, severe insufficiency may manifest in the African American population as increased risk for these other conditions rather than as increased risk for skeletal conditions. Indeed, recent studies suggest that hypovitaminosis $\mathrm{D}$ in African Americans may contribute to their higher risk of peripheral arterial disease [34] and high blood pressure [35] relative to whites. Future efforts should focus on reconsidering intake recommendations and increasing vitamin D intake, such as through supplementation, in order to improve vitamin D status in this population.

\section{List of Abbreviations}

25(OH)D: 25-hydroxyvitamin D; BMI: body mass index; FCCC: Fox Chase Cancer Center; PRAP: Prostate Cancer Risk Assessment Program.

\section{Competing interests}

The authors declare that they have no competing interests.

\section{Authors' contributions}

MT was responsible for initiating the study, analyzing the data, and drafting the manuscript. VG and DB contributed to the design of the study, provided information on the Prostate Cancer Risk Assessment Program, and contrib- uted to drafts of the manuscript. EG contributed to the study concept, interpretation of results, and suggestions towards subsequent drafts of the manuscript. All authors read and approved the final manuscript.

\section{Acknowledgements}

The authors thank the participants of the Prostate Cancer Risk Assessment Program at Fox Chase Cancer Center. We also thank Ms. Susan Raysor, Ms. JoEllen Weaver, and Dr. Cynthia Spittle for bringing together the necessary datasets and plasma samples from the Prostate Cancer Risk Assessment Program; Dr. Mustafa Dosemeci for sharing his occupational sunlight exposure index; Dr. Kaye Brock for her comments on the manuscript; and Dr. Ronald Horst for his assistance in conducting the vitamin D assays. This work was supported by grants R03 CAI 10892 and P30 CA006927 from the National Institutes of Health.

\section{References}

I. Holick MF, Chen TC: Vitamin D deficiency: a worldwide problem with health consequences. Am J Clin Nutr 2008, 87:1080S-1086S.

2. Harris SS: Vitamin D and African Americans. J Nutr 2006, 136: I I26-II29.

3. Liu PT, Stenger S, Li H, Wenzel L, Tan BH, Krutzik SR, Ochoa MT, Schauber J, Wu K, Meinken C, et al.: Toll-like receptor triggering of a vitamin D-mediated human antimicrobial response. Science 2006, 3II:1770-1773.

4. Clemens TL, Adams JS, Henderson SL, Holick MF: Increased skin pigment reduces the capacity of skin to synthesise vitamin D3. Lancet 1982, I:74-76.

5. Institute of Medicine, National Academy of Sciences: Dietary Reference Intakes for Calcium, Phosphorous, Magnesium, Vitamin D, and Fluoride Washington, DC: National Academy Press; 1997.

6. Hannan MT, Litman HJ, Araujo AB, McLennan CE, McLean RR, McKinlay JB, Chen TC, Holick MF: Serum 25-hydroxyvitamin D and bone mineral density in a racially and ethnically diverse group of men. J Clin Endocrinol Metab 2008, 93:40-46.

7. Harris SS, Soteriades E, Coolidge JA, Mudgal S, Dawson-Hughes B: Vitamin $D$ insufficiency and hyperparathyroidism in a low income, multiracial, elderly population. J Clin Endocrinol Metab 2000, 85:4125-4I30.

8. Bruner DW, Baffoe-Bonnie A, Miller S, Diefenbach M, Tricoli JV, Daly M, Pinover W, Grumet SC, Stofey J, Ross E, et al.: Prostate cancer risk assessment program. A model for the early detection of prostate cancer. Oncology 1999, 13:325-334. discussion 337-329, 343-324 pas

9. Willett WC, Sampson L, Browne ML, Stampfer MJ, Rosner B, Hennekens $\mathrm{CH}$, Speizer FE: The use of a self-administered questionnaire to assess diet four years in the past. Am J Epidemiol 1988, 127:188-199.

10. Freedman DM, Zahm SH, Dosemeci M: Residential and occupational exposure to sunlight and mortality from non-Hodg. kin's lymphoma: composite (threefold) case-control study. Br Med J 1997, 3 I 4: | 451|-1455.

II. Freedman DM, Dosemeci M, Alavanja MC: Mortality from multiple sclerosis and exposure to residential and occupational solar radiation: a case-control study based on death certificates. Occup Environ Med 2000, 57:4I8-42I.

12. Freedman DM, Dosemeci M, McGlynn K: Sunlight and mortality from breast, ovarian, colon, prostate, and non-melanoma skin cancer: a composite death certificate based case-control study. Occup Environ Med 2002, 59:257-262.

13. Ersfeld DL, Rao DS, Body JJ, Sackrison JL Jr, Miller AB, Parikh N, Eskridge TL, Polinske A, Olson GT, MacFarlane GD: Analytical and clinical validation of the $25 \mathrm{OH}$ vitamin $\mathrm{D}$ assay for the LIAISON automated analyzer. Clin Biochem 2004, 37:867-874.

14. Nesby-O'Dell S, Scanlon KS, Cogswell ME, Gillespie C, Hollis BW, Looker AC, Allen C, Doughertly C, Gunter EW, Bowman BA: Hypovitaminosis $D$ prevalence and determinants among African American and white women of reproductive age: third National Health and Nutrition Examination Survey, 19881994. Am J Clin Nutr 2002, 76:187-192. 
15. Jacques PF, Felson DT, Tucker KL, Mahnken B, Wilson PW, Rosenberg IH, Rush D: Plasma 25-hydroxyvitamin D and its determinants in an elderly population sample. Am J Clin Nutr 1997, 66:929-936.

16. Heaney RP: Functional indices of vitamin D status and ramifications of vitamin D deficiency. Am J Clin Nutr 2004, 80: I706S-1709S.

17. Egan KM, Signorello LB, Munro HM, Hargreaves MK, Hollis BW, Blot W]: Vitamin $D$ insufficiency among African-Americans in the southeastern United States: implications for cancer disparities (United States). Cancer Causes Control 2008, 19:527-535.

18. Yanoff LB, Parikh SJ, Spitalnik A, Denkinger B, Sebring NG, Slaughter $\mathrm{P}$, McHugh T, Remaley AT, Yanovski JA: The prevalence of hypovitaminosis $D$ and secondary hyperparathyroidism in obese Black Americans. Clin Endocrinol (Oxf) 2006, 64:523-529.

19. Bischoff-Ferrari HA, Giovannucci E, Willett WC, Dietrich T, DawsonHughes B: Estimation of optimal serum concentrations of 25 hydroxyvitamin $\mathbf{D}$ for multiple health outcomes. Am J Clin Nutr 2006, 84: 18-28.

20. Jacobs ET, Alberts DS, Foote JA, Green SB, Hollis BW, Yu Z, Martinez ME: Vitamin D insufficiency in southern Arizona. Am J Clin Nutr 2008, 87:608-613.

21. Zadshir A, Tareen N, Pan D, Norris K, Martins D: The prevalence of hypovitaminosis D among US adults: data from the NHANES III. Ethn Dis 2005, I 5(S5):97-I0I.

22. Binkley N, Krueger D, Cowgill CS, Plum L, Lake E, Hansen KE, DeLuca HF, Drezner MK: Assay variation confounds the diagnosis of hypovitaminosis D: a call for standardization. J Clin Endocrinol Metab 2004, 89:3 I52-3I 57.

23. Souberbielle JC, Fayol V, Sault C, Lawson-Body E, Kahan A, Cormier C: Assay-specific decision limits for two new automated parathyroid hormone and 25-hydroxyvitamin D assays. Clin Chem 2005, 5 I:395-400.

24. Looker AC, Dawson-Hughes B, Calvo MS, Gunter EW, Sahyoun NR: Serum 25-hydroxyvitamin $D$ status of adolescents and adults in two seasonal subpopulations from NHANES III. Bone 2002, 30:77I-777.

25. Neuhouser ML, Sorensen B, Hollis BW, Ambs A, Ulrich CM, McTiernan A, Bernstein L, Wayne S, Gilliland F, Baumgartner $K$, et al: Vitamin $D$ insufficiency in a multiethnic cohort of breast cancer survivors. Am J Clin Nutr 2008, 88:133-139.

26. Scragg R, Camargo CA Jr: Frequency of leisure-time physical activity and serum 25-hydroxyvitamin D levels in the US population: results from the Third National Health and Nutrition Examination Survey. Am / Epidemiol 2008 , 168:577-586. discussion 587-59|

27. Scragg R, Holdaway I, Singh V, Metcalf P, Baker J, Dryson E: Serum 25-hydroxyvitamin D3 is related to physical activity and ethnicity but not obesity in a multicultural workforce. Aust $N Z J$ Med 1995, 25:218-223.

28. van Dam RM, Snijder MB, Dekker JM, Stehouwer CD, Bouter LM, Heine RJ, Lips P: Potentially modifiable determinants of vitamin $D$ status in an older population in the Netherlands: the Hoorn Study. Am J Clin Nutr 2007, 85:755-76I.

29. Visscher TL, Seidell JC: Time trends (1993-1997) and seasonal variation in body mass index and waist circumference in the Netherlands. Int J Obes Relat Metab Disord 2004, 28:1309-1316.

30. Shahar DR, Froom P, Harari G, Yerushalmi N, Lubin F, Kristal-Boneh $\mathrm{E}$ : Changes in dietary intake account for seasonal changes in cardiovascular disease risk factors. Eur J Clin Nutr 1999, 53:395-400.

31. Wortsman J, Matsuoka LY, Chen TC, Lu Z, Holick MF: Decreased bioavailability of vitamin $\mathbf{D}$ in obesity. Am J Clin Nutr 2000, 72:690-693.

32. Looker AC: Body fat and vitamin D status in black versus white women. J Clin Endocrinol Metab 2005, 90:635-640.

33. Epstein S, Bell NH, Shary J, Shaw S, Greene A, Oexmann MJ: Evidence that obesity does not influence the vitamin $D$-endocrine system in blacks. J Bone Miner Res 1986, I:181-184.

34. Reis JP, Michos ED, von Muhlen D, Miller ER 3rd: Differences in vitamin $D$ status as a possible contributor to the racial disparity in peripheral arterial disease. The American journal of clinical nutrition 2008, 88: 1469-1477.

35. Scragg R, Sowers M, Bell C: Serum 25-hydroxyvitamin D, ethnicity, and blood pressure in the Third National Health and
Nutrition Examination Survey. Am J Hypertens 2007, 20:7|3-7|9.

\section{Pre-publication history}

The pre-publication history for this paper can be accessed here:

http://www.biomedcentral.com/1471-2458/9/191/pre pub
Publish with Bio Med Central and every scientist can read your work free of charge

"BioMed Central will be the most significant development for disseminating the results of biomedical research in our lifetime. "

Sir Paul Nurse, Cancer Research UK

Your research papers will be:

- available free of charge to the entire biomedical community

- peer reviewed and published immediately upon acceptance

- cited in PubMed and archived on PubMed Central

- yours - you keep the copyright 